\title{
HIDROLISIS SELULOSA MENJADI GLUKOSA DENGAN KATALIS HETEROGEN ARANG AKTIF TERSULFONASI
}

\author{
Didi Dwi Anggoro ${ }^{*}$, Purwanto, dan Rispiandi \\ Jurusan Teknik Kimia Fakultas Teknik, Universitas Diponegoro \\ Jl. Prof. Soedarto, SH, Tembalang, Semarang 50275 \\ *)Penulis korespondensi: anggorophd@gmail.com
}

\begin{abstract}
CELLULOCE HYDROLYSIS TO GLUCOSE USING ACTIVE CARBON SULPHONATED HETEROGENOUS CATALYST. Enzimatic process and acid hydrolysis process are common process for conversion of cellulose to glucose. Unfornately, the two processes are expensive process and korosif process. Hence, the new process, that use sulfonaned active carbon catalyst is important to developing. The sulfonated active carbon is made from carbonated coconut sheel under temperature at $350^{\circ} \mathrm{C}$. After carbonation, sulfonated active carbon soaked under sulphate acid $96 \%$ at $150^{\circ} \mathrm{C}$ until 15 hours. The result is then washed and dried, and tested catalyst characteristics in the form of $H^{+}$capacity, pore size catalysts by used BET surface area, functional groups by used FTIR, and morphology catalyst structure by used SEM. Catalyst performance was tested in an autoclave reactor through a hydrothermal process with difference of the catalyst amount and temperature. The results showed that the test characteristics of $\mathrm{H}^{+}$capacity is $2.95 \mathrm{mmol} / \mathrm{g}$, the pore size is $29 \mathrm{~m} 2 / \mathrm{gr}$. FTIR analyze showed that the presence of sulfonate groups read at a wavelength of vibration $1750 \mathrm{~cm}$. ${ }^{1}$ and $1379 \mathrm{~cm}^{-1}$. By SEM analyze showed that the morphological structure of sulfonated active carbon is more open than other catalyst. By testing catalyst, the highest conversion of glucose is $87.2 \%$.
\end{abstract}

Keywords : cellulose; glucose; sulfonate active carbon; thatch

\begin{abstract}
Abstrak
Teknologi yang sudah digunakan dalam mengubah selulosa menjadi glukosa adalah dengan proses enzimatik dan hidrolisis asam. Kedua teknologi tersebut masih memiliki kendala teknis, yaitu harga enzim yang mahal, proses yang korosif dan menimbulkan limbah, sehingga diperlukan pengembangan teknologi baru salah satu diantaranya yaitu dengan metode katalis heterogen berupa karbon aktif tersulfonasi. Karbon aktif tersulfonasi ini dibuat dari tempurung kelapa yang dikarbonisasi pada temperatur $350^{\circ} \mathrm{C}$, selanjutnya direndam dalam asam sulfat $96 \%$ pada temperatur $150^{\circ} \mathrm{C}$ selama 15 jam. Hasilnya kemudian dicuci dan dikeringkan, dilakukan uji karakteristik dan performance (kinerja ) katalis berupa kapasitas $\mathrm{H}^{+}$, ukuran pori katalis dengan BET, uji gugus fungsi dengan FTIR, dan uji struktur marfologi katalis dengan SEM. Kinerja katalis diuji dalam reaktor autoclave melalui proses hidrotermal dengan mevariasikan jumlah katalis, dan variasi temperatur. Hasil penelitian menunjukkan untuk uji karakteristik kapasitas $H^{+}$sebesar 2,95 mmol/gr, untuk uji BET ukuran pori 29 $\mathrm{m}^{2} / g r$, untuk uji FTIR keberadaan gugus sulfonat terbaca pada vibrasi panjang gelombang $1750 \mathrm{~cm}^{-1}$ dan $1379 \mathrm{~cm}^{-1}$, pada uji SEM struktur morfologi katalis yang lebih terbuka pada karbon aktif setelah proses sulfonasi. Kinerja katalis konversi tertinggi selulosa menjadi glukosa mencapai 87,2\% pada jumlah alang-alang $2 \mathrm{gr}$, jumlah katalis $2 \mathrm{gr}$, dan temperatur $170^{\circ} \mathrm{C}$ selama 8 jam.
\end{abstract}

Kata kunci : selulosa; glukosa; karbon aktif tersulfonasi; alang-alang

How to Cite This Article: Anggoro, D.D., Purwanto, dan Rispiandi, (2014), Hidrolisis Selulosa Menjadi Glukosa dengan Katalis Heterogen Arang Aktif Tersulfonasi, Reaktor, 15(2), 126-131, http://dx.doi.org/ 10.14710/reaktor.15.2.126-131

\section{PENDAHULUAN}

Biomassa memiliki potensi yang kaya akan bahan lignoselulosa. Sekarang ini di negara-negara maju mulai dilakukan penelitian dan pengembangan bahkan sudah ada sampai ke tingkat produksi bagaimana mengubah bahan biomassa tersebut menjadi bioetanol (Alico dkk., 1982). Bioetanol ini diharapkan berangsur-angsur menjadi bahan bakar 
alternatif pengganti bensin. Seperti yang kita ketahui bahwa bahan bakar bensin ini diperoleh dari hasil pengilangan minyak mentah, sementara harga minyak mentah dunia cenderung fluktuatif, sedangkan impor minyak mentah dan hasil olahannya untuk kebutuhan dalam negeri juga semakin meningkat, maka dibutuhkan berbagai langkah strategis untuk menghemat cadangan energi konvensional, menjaga ketersediaan energi, serta mengurangi pembelanjaan devisa dari sektor ini (Kosaric dkk., 1981). Di samping itu, penggunaan energi fosil telah menimbulkan emisi berbagai gas yang menjadi polutan berbahaya di udara.

Selulosa dibuat menjadi etanol dengan tahapan selulosa diubah menjadi glukosa, kemudian glukosa diubah menjadi etanol. Teknologi yang sudah digunakan selama ini adalah dengan proses enzimatik dan hidrolisis asam. Kedua teknologi tersebut masih memiliki kendala teknis (Tabel 1), yaitu untuk proses enzimatik harga enzim yang mahal dan rentan terhadap perubahan kondisi operasi sedangkan hidrolisis asam prosesnya korosif dan menimbulkan limbah, sehingga diperlukan pengembangan teknologi baru untuk memperbaiki persoalan teknis tersebut.

Dengan tujuan memperbaiki permasalahan teknis penggunaan asam maka dibuat katalis padat arang aktif tersulfonasi. Arang tersulfonasi ini dibuat dengan mereaksikan arang aktif (karbon aktif) dengan asam asam sulfat, diharapkan gugus sulfonat yang mengandung gugus $\mathrm{H}^{+}$bisa bertindak sebagai asam.

Teknologi dengan katalis arang tersulfonasi adalah teknologi baru yang sedang berkembang dan diteliti di Jepang, dari beberapa kajian katalis tersebut mampu mengubah selulosa menjadi glukosa. Onda dkk. (2008) melakukan riset penelitian terhadap beberapa katalis padat seberapa besar kemampuannya mengubah selulosa menjadi glukosa. Hasil penelitian menunjukkan karbon aktif tersulfonasi memiliki unjuk kerja terbaik menghasilkan konversi yang paling tinggi. Hasil riset itu menunjukkan katalis karbon aktif tersulfonasi memiliki konversi yang lebih tinggi dari katalis yang lain. Katalis padat karbon aktif tersulfonasi yang digunakan dari bahan dasar gula yang diubah menjadi karbon dengan proses pirolisis $\left(\mathrm{T}>300^{\circ} \mathrm{C}\right)$ kemudian disulfonasi dengan asam sulfat pada temperatur $150^{\circ} \mathrm{C}$.

Syarat karbon yang digunakan sebagai support katalis harus dalam bentuk struktur polyaromatik hidrokarbon. Pada struktur polyaromatik hidrokarbon katalis gugus sulfonat memungkinkan untuk dilekatkan. Dengan demikian proses karbonisasi dilakukan pada temperatur $\pm 400^{\circ} \mathrm{C}$, untuk membentuk struktur poliaroamatik (Mochida dkk., 2006)

Keuntungan karbon aktif sebagai support katalis (Mochida dkk., 2006) adalah: tahan asam dan basa, tahan temperatur dan tekanan tinggi, bersifat inert, mudah di daur ulang (recovery), dan memiliki luas permukaan yang besar. Setelah proses pembuatan carbon aktif dilakukan langkah berikutnya disulfonasi dengan asam sulfat pada temperatur $150^{\circ} \mathrm{C}$. Gugus sulfonat diharapkan terikat pada struktur aromatiknya.

Penggunaan katalis padat tersebut memiliki keunggulan proses tidak korosif ( $\mathrm{pH}$ normal), apabila proses selesai pemisahan mudah dengan cara filtrasi, kemudian setelah katalis padat dipisahkan bisa diaktifkan (dipergunakan) kembali. Sehingga produk katalis ini tidak menghasilkan limbah (Koyotaka dan Michikazu, 2007)

Kebaharuan penelitian ini adalah penggunaan langsung alang-alang sebagai sumber selulosa sebagai bahan baku. Sedangkan peneliti sebelumnya (Onda dkk., 2008; Onda dkk., 2009) memakai selulosa murni sebagai reaktan. Hasil penelitian ini diharapkan dapat digunakan sebagai dasar pengembangan proses sumber alam yang banyak mengandung selulosa menjadi glukosa, yang akhirnya dapat sebagai bahan produksi bioetanol.

\section{METODE PENELITIAN}

Bahan-bahan yang digunakan adalah :Arang aktif dari tempurung kelapa, larutan $\mathrm{H}_{2} \mathrm{SO}_{4}$ pekat, dan bahan-bahan selulosa (tongkol jagung, alang-alang, dan sekam padi). Alat yang digunakan adalah autoclave untuk proses hidrolisis (Gambar 1).

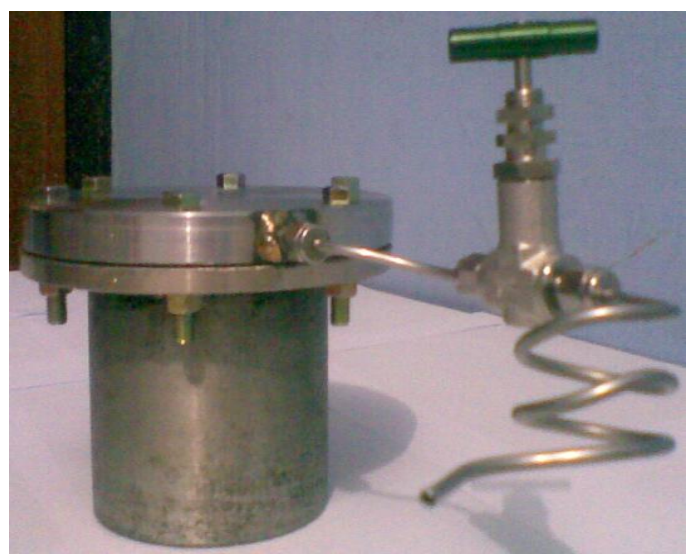

Gambar 1. Autoclave untuk hidrolisis katalisis

Tabel 1. Perbandingan antara hidrolisis asam dan hidrolisis enzimatik (Taherzadeh dan Karimi, 2007a; 2007b )

\begin{tabular}{lcc}
\hline Variabel Pembanding & Hidrolisis Asam & Hidrolisis Enzimatik \\
\hline Kondisi hidrolisis yang 'lunak' (mild) & Tidak & Ya \\
Hasil hidrolisis tinggi & Tidak & Ya \\
Penghambatan produk selama hidrolisis & Tidak & Ya \\
Pembentukan produk samping yang menghambat & Ya & Tidak \\
Katalis yang murah & Ya & Tidak \\
Waktu hidrolisis yang murah & Ya & Tidak \\
\hline
\end{tabular}


Spesifikasi alat autoclave yang dibuat memiliki spesifikasi : volume $250 \mathrm{ml}$, tinggi $11 \mathrm{~cm}$, terbuat dari bahan SS 304, seperti pada Gambar 1. Autoclave dilengkapi dengan keran sampling, bagian atas autoclave menggunakan flange (sambungan baut) untuk keluar masuk bahan, pemanasan autoclave menggunakan oven furnace, pengaduk menggunakan magnetik stirrer.

Uji bahan alam dilakukan terhadap tiga bahan alam (tongkol jaung, alang-alang, dan sekam). Bahan alam tersebut dipanaskan pada temperatur $105^{\circ} \mathrm{C}$, kemudian dikecilkan ukurannya hingga 60 mesh. Hasilnya kemudian diuji untuk mengetahui kandungan hemiselulosa, selulosa, lignin, dan derajat polimerisasi. Hasil uji tersebut dipilih bahan alam yang paling optimum. Tahapan analisa terdapat pada Gambar 2.

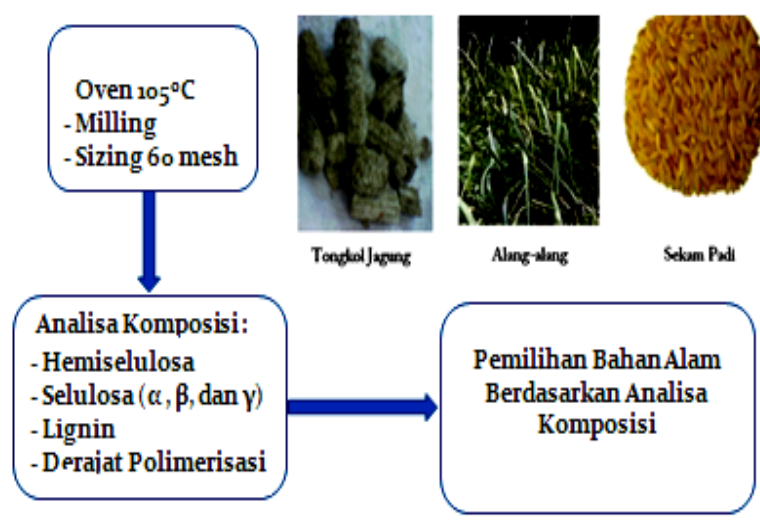

Gambar 2. Skema analisa bahan alam

Gambar 3 menggambarkan tahapan/langkah pembuatan dan karakterisasi katalis. Tempurung kelapa yang didapat dimasukkan dalam furnace kemudian dipanaskan pada suhu $350^{\circ} \mathrm{C}$ selama 5 jam. Arang/karbon aktif yang terbentuk dikecilkan ukurannya hingga 60 mesh, kemudian direndam dalam asam sulfat $96 \%$ selama 15 jam pada suhu $150^{\circ} \mathrm{C}$. Hasilnya dicuci dfan dikeringkan, kemudian diuji karakteristik katalis tersebut dengan: uji $\mathrm{H}^{+}$capacity, BET, FTIR, dan SEM.
Pengaruh jumlah katalis terhadap konversi reaksi dilakukan 5 variasi berat katalis : $\mathrm{W}_{1}, \mathrm{~W}_{2}, \mathrm{~W}_{3}$, $\mathrm{W}_{4}$ dan $\mathrm{W}_{4}$, variabel lain dibuat tetap yaitu konsentrasi bahan awal dan temperatur. Dilakukan pengamatan seberapa besar pengaruhnya terhadap konversi reaksi (X).

Pengaruh temperatur reaksi terhadap konversi reaksi dilakukan 5 variasi temperatur: $\mathrm{T}_{1}, \mathrm{~T}_{2}, \mathrm{~T}_{3}, \mathrm{~T}_{4}$, dan $\mathrm{T}_{5}$, variabel lain dibuat tetap yaitu konsentrasi bahan awal dan jumlah katalis. Dilakukan pengamatan seberapa besar pengaruhnya terhadap konversi reaksi (X).

Analisa produk glukosa menggunakan metode Antrone $\quad\left(9,10\right.$-dihydro-9-0xsanthracene/ $\left.\mathrm{C}_{14} \mathrm{H}_{10} \mathrm{O}\right)$ $0,1 \%$ dalam asam sulfat. Pembuatan kurva standar gula total dilakukan dengan cara melarutkan $0,1 \mathrm{~g}$ glukosa standar dalam $100 \mathrm{~mL}$ aquades sehingga diperoleh konsentrasi 1000 ppm. Larutan kemudian diencerkan dengan aquades sehingga diperoleh konsentrasi 0 (kontrol); 40; 80; 120; 160; 200 ppm. Masing-masing larutan tersebut kemudian ditambah dengan $5 \mathrm{~mL}$ pereaksi Anthrone, kemudian ditutup dan dicampur secara merata. Setelah ditempatkan dalam penangas air (water bath) $100^{\circ} \mathrm{C}$ selama 12 menit, dan didinginkan dengan air mengalir, kemudian dilakukan pembacaan absorbansinya pada spektrometer panjang gelombang maksimum $630 \mathrm{~nm}$ dibuat hubungan antara absorbansi dengan mg glukosa. Penetapan konsentrasi gula total yang terkandung dalam sampel dilakukan pada $1 \mathrm{~mL}$ sampel yang telah diencerkan dalam tabung reaksi dengan cara yang sama seperti pada pembuatan kurva standar.

\section{HASIL DAN PEMBAHASAN}

Pada Tabel 2 diperoleh $\alpha$-selulosa tertinggi pada sekam yaitu $43,91 \%$, sedangkan untuk alangalang 39,53\%. Di dalam penelitian kami memilih alang-alang sebagai bahan alam sebagai sumber selulosa, karena sekam mengandung unsur silika yang bisa menimbulkan kerak pada reaktor dan mempengaruhi kerja katalis.

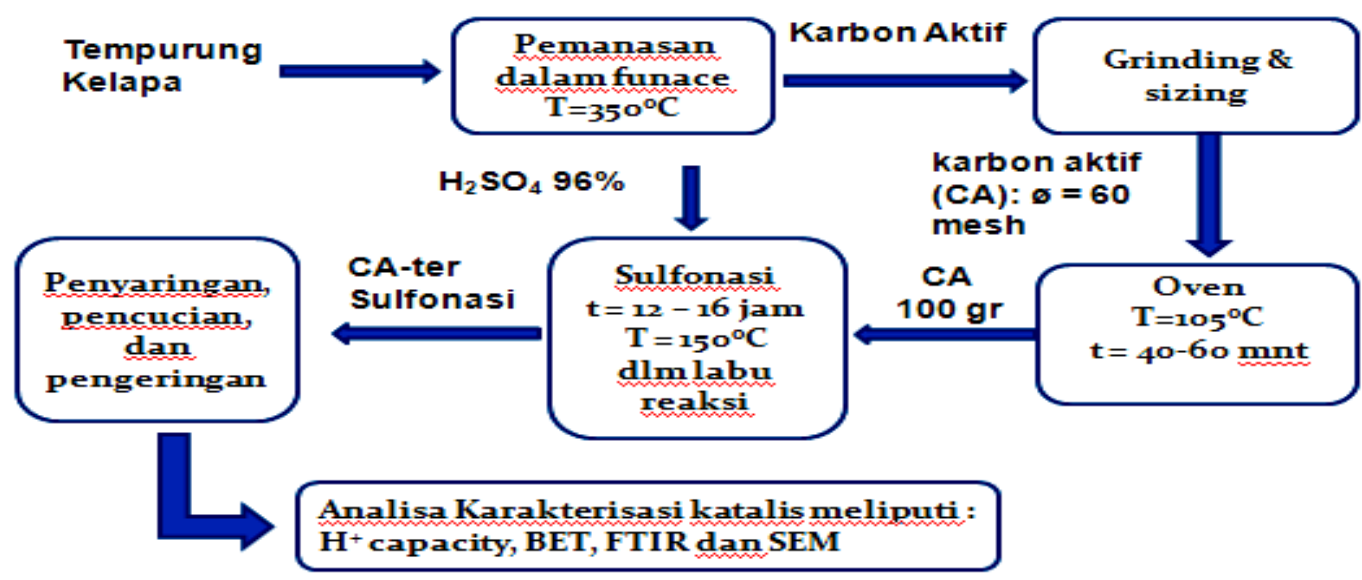

Gambar 3. Skema pembuatan katalis 
Tabel 2. Hasil analisa bahan alam

\begin{tabular}{ccccc}
\hline No & Parameter Pengujian & Alang-alang & Sekam & Tongkol Jagung \\
\hline 1. & Kadar Pentosan sebagai Hemiselulosa, $\%$ & 23,92 & 19,07 & 30,91 \\
2. & Kadar Holoselulosa, \% & 71,58 & 78,01 & 64,17 \\
3. & Kadar $\alpha$-selulosa, \% & 39,53 & 43,91 & 28,93 \\
4. & Kadar $\beta$-selulosa, \% & 1,59 & 11.27 & - \\
5. & Kadar $\gamma$-selulosa, \% & 30,46 & 22.83 & 48,51 \\
6. & Kadar Lignin, $\%$ & 23,33 & 42,74 & 15,52 \\
7. & Derajat Polimerisasi & 1600 & 857 & - \\
\hline
\end{tabular}

Alasan lain yang menjadi dasar pemilihan alang-alang adalah, mudah di dapat, dapat dipanen seperti jerami, tidak saling menindih/menimpa satu sama lain, ketika tumbuhan sudah tinggi, tanaman yang menahun lebih tahan kekeringan, lebih tahan hama, dan lebih tak mengerosi tanah dibanding tanaman semusim.

\section{Hasil Karakterisasi Katalis}

Uji karakteristik katalis dimaksudkan untuk mengetahui apakah katalis heterogen karbon aktif tersulfonasi benar-benar terbentuk atau tidak. Hasil uji kapasitas $\mathrm{H}^{+}$diperoleh jumlah $\mathrm{H}^{+}$dalam katalis adalah $2,95 \mathrm{mmol} / \mathrm{gr}$, berarti dalam 1 gr katalis terdapat 2,95 mmol ion $\mathrm{H}^{+}$. Ion $\mathrm{H}^{+}$inilah yang terikat pada gugus sulfonat yang di harapkan berperan sebagai katalis dalam proses hidrolisis untuk memecah selulosa menjadi glukosa (Onda dkk., 2008). Hasil uji BET diperoleh luas permukaan katalis sebesar $29 \mathrm{~m}^{2} / \mathrm{gr}$. Luas permukaan katalis ini diharapkan berperan dalam interaksi pusat aktif dengan selulosa pada permukaan katalis (Mochida dkk. 2006).

Dari hasil uji FTIR karbon aktif tersulfonasi dibandingkan dengan FTIR carbon aktif (Gambar 4), diperoleh perbedaan pita puncak vibrasi pada panjang gelombang $\lambda=1750 \mathrm{~cm}^{-1}$ dan $\lambda=1379 \mathrm{~cm}^{-1}$. Pada panjang gelombang tersebut terdeteksi keberadaan gugus sulfonat $\mathrm{SO}_{3} \mathrm{H}$. Dengan demikian, FTIR menunjukkan bukti bahwa karbon aktif setelah sulfonasi mengandung gugus sulfonat sebagai bagian aktif (active site) dari katalis karbon aktif.

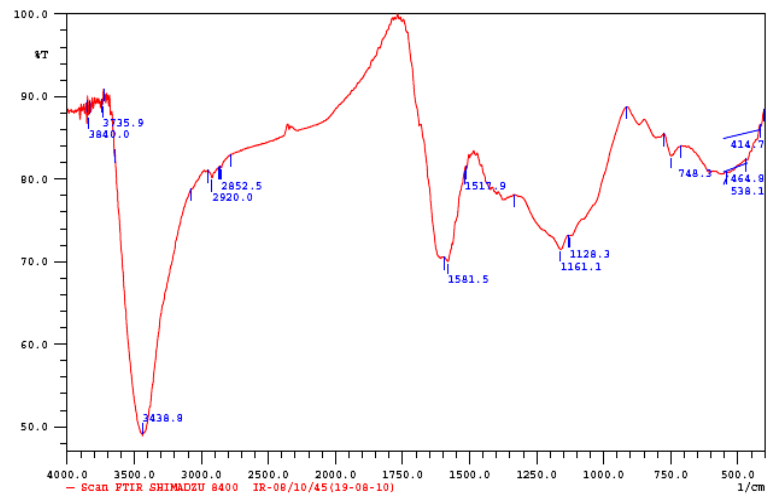

(a)

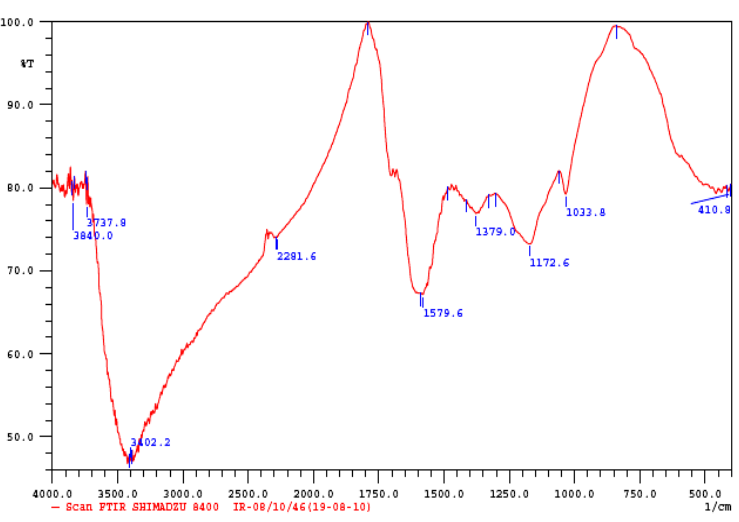

(b)

Gambar 4. (a) FTIR arang aktif, (b) FTIR arang aktif tersulfonasi

Hasil uji SEM tampak bentuk morfologi permukaan katalis bersifat amorf (tersusun tidak teratur) sehingga peluang terjadinya reaksi makin besar (Gambar 5). Bentuk permukaan katalis berpengaruh terhadap interaksi proses reaksi. Untuk SEM karbon aktif tersulfonasi tampak struktur permukaannya lebih terbuka dibandingkan dengan karbon aktif sebelum disulfonasi.

Dengan pembesaran yang sama $1.000 \mathrm{x}$ terlihat bahwa struktur morfologi dari karbon aktif yang disulfonasi lebih terbuka, sehingga reaktan (selulosa) lebih mudah masuk ke permukaan katalis sehingga dimungkinkan bisa lebih mudah berinteraksi dengan gugus $\mathrm{H}^{+}$yang terikat di permukaan dan membentuk glukosa.

Dari Uji SEM EDX (Gambar 6) diperoleh hasil bahwa karbon aktif tersulfonasi mengandung kandungan belerang (S) sebesar 2,61\%, sedangkan pada karbon aktif tidak terdapat unsur $\mathrm{S}$. Unsur $\mathrm{S}$ ini merupakan gugus sulfonat yang terikat pada karbon aktif. Hasil ini menguatkan keberadaan gugus sulfonat seperti pada uji kualitatif FTIR. Dengan ini dapat diprediksikan bahwa pembakaran karbon pada temperatur tertentu membentuk struktur poliaromatik hidrokarbon, sehingga memungkinkan untuk menjadi support melekatkan gugus sulfonat sebagai pusat aktif katalis. 


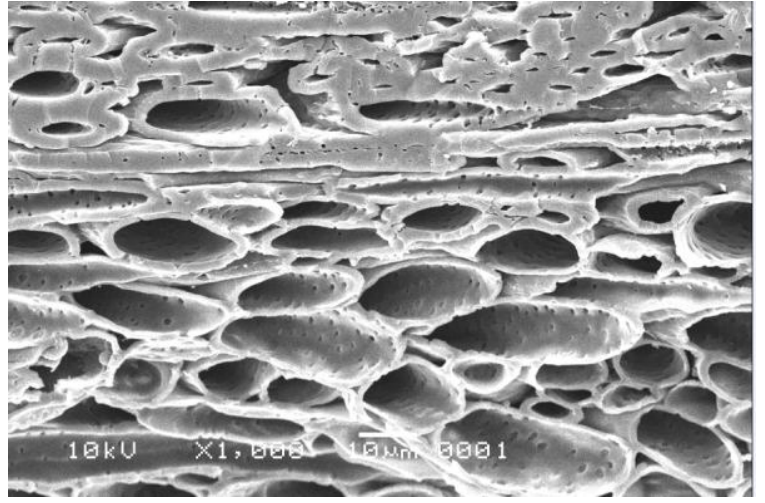

(a)

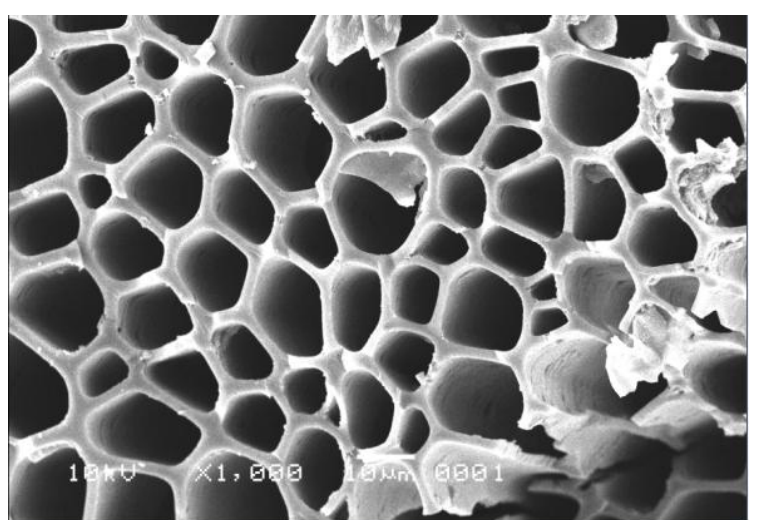

(b)

Gambar 5. (a) SEM karbon aktif, (b) SEM karbon aktif sulfonat perbesaran 1000x

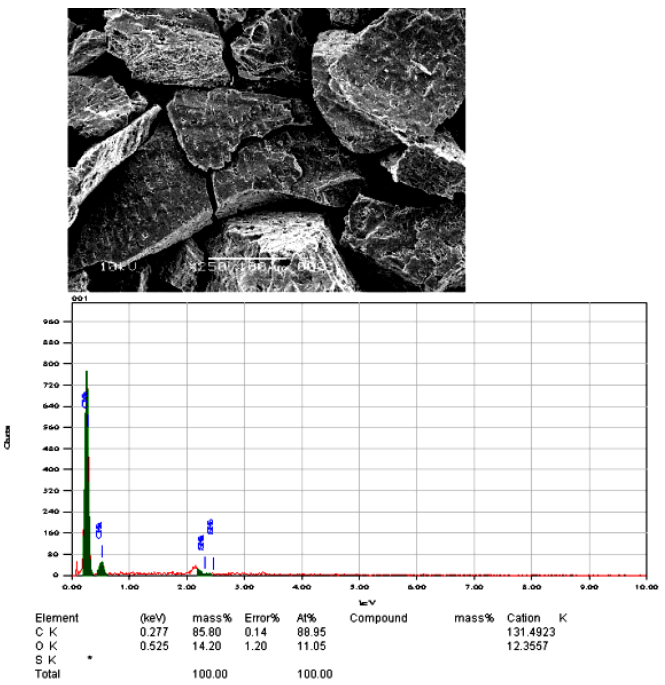

(a)

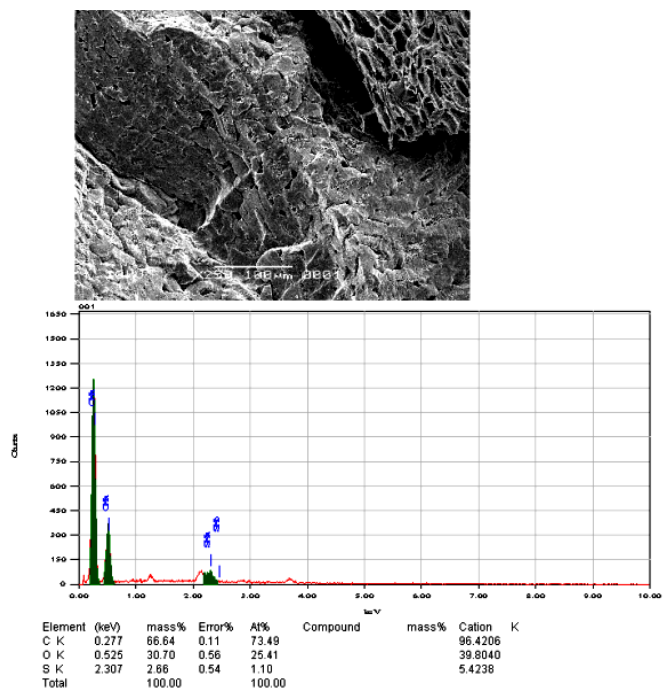

(b)

Gambar 6. (a) SEM EDX karbon aktif perbesaran 250x (b) SEM EDX karbon aktif sulfonat perbesaran 250x

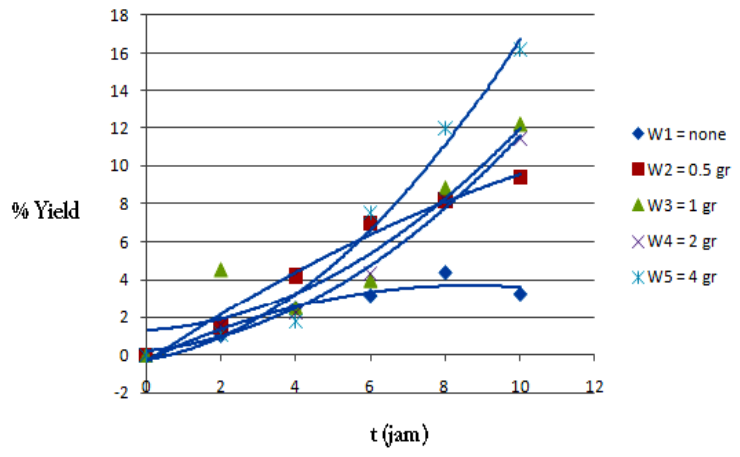

Gambar 7. Pengaruh jumlah katalis terhadap \% yield alang-alang

\section{Hasil Uji Kinerja Katalis}

Dari Gambar 7 dan 8 diperoleh bahwa jumlah katalis berpengaruh secara signifikan terhadap reaksi selulosa menjadi glukosa. Dari grafik tampak \% yield alang-alang maupun \% konversi selolusa semakin meningkat. Hal ini disebabkan makin banyak katalis, makin banyak proton $\mathrm{H}^{+}$yang berperan dalam reaksi

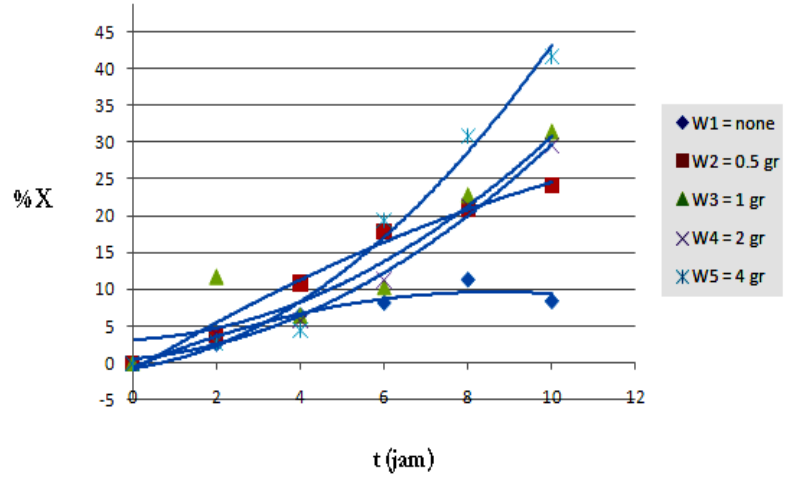

Gambar 8. Pengaruh jumlah katalis terhadap \% konversi selulosa menjadi glukosa

kimia. Sesuai dengan Xiang dkk. (2003) yang menyimpulkan bahwa semakin tinggi konsentrasi asam, waktu reaksi makin cepat karena gugus $\mathrm{H}^{+}$ makin banyak tersedia. Sehingga dengan semakin banyak katalis yang dipakai dalam variabel ini, mengakibatkan \% yield dan konversi selulosa menjadi glukosa juga meningkat. 
Dari Gambar 9 dan 10 diperoleh bahwa temperatur berpengaruh secara signifikan terhadap reaksi selulosa menjadi glukosa. Dari grafik tampak \% yield alang-alang maupun \% konversi selolusa semakin meningkat. Meningkatnya temperatur menyebabkan energi aktivasinya bertambah, interaksi molekuler menjadi meningkat (Xiang dkk., 2003). Faktor temperatur berpengaruh juga dalam hal membantu penetrasi lepasnya ikatan selulosa dari alang-alang.

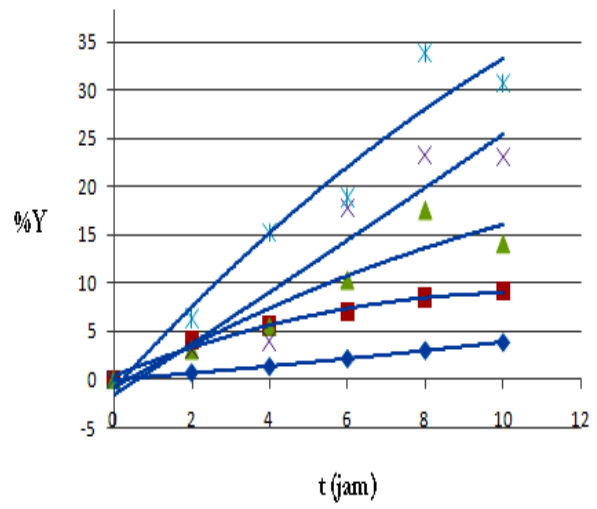

$\rightarrow T 1=130 \mathrm{C}$

- $\mathrm{T} 2=140 \mathrm{C}$

$\triangle \mathrm{T} 3=150 \mathrm{C}$

$X \mathrm{~T} 4=160 \mathrm{C}$

$T 5=170 \mathrm{C}$

Gambar 9. Pengaruh temperatur terhadap \% yield alang-alang menjadi glukosa

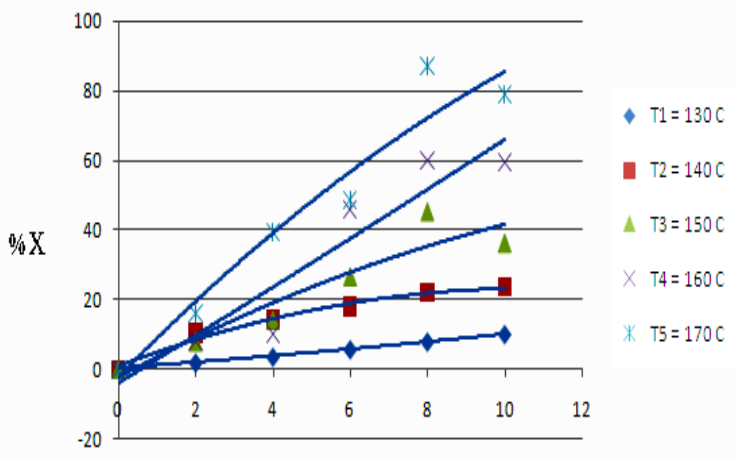

$t(j \mathrm{jam})$

Gambar 10. Pengaruh temperatur terhadap \% konversi selulosa menjadi glukosa

\section{KESIMPULAN}

Arang aktif tersulfonasi memenuhi syarat sebagai katalis heterogen karena memiliki karakteristik : kapasitas ion $\mathrm{H}^{+}$, luas permukaan yang besar, memiliki gugus sulfonat tempat melekatkan $\mathrm{H}^{+}$, dan struktur morfologi yang bersifat amorf. Hasil karakterisasi kapasitas $\mathrm{H}^{+}$sebesar 2,95 $\mathrm{mmol} / \mathrm{gr}$, untuk uji BET ukuran pori $29 \mathrm{~m}^{2} / \mathrm{gr}$, untuk uji FTIR keberadaan gugus sulfonat terbaca pada vibrasi panjang gelombang $1750 \mathrm{~cm}^{-1}$ dan $1379 \mathrm{~cm}^{-1}$, pada uji SEM struktur morfologi katalis yang lebih terbuka pada karbon aktif setelah proses sulfonasi. Kinerja katalis konversi tertinggi selulosa menjadi glukosa mencapai $87,2 \%$ pada jumlah alang-alang 2 gr, jumlah katalis $2 \mathrm{gr}$, dan temperatur $170^{\circ} \mathrm{C}$ selama 8 jam. Arang aktif tersulfonasi memiliki prospek sebagai katalis padat untuk menghidrolisis selulosa menjadi glukosa, sehingga bisa dijadikan solusi untuk memperbaiki persoalan-persoalan teknis pada proses enzimatik dan hidrolisis asam.

\section{DAFTAR PUSTAKA}

Alico, D.H., (1982), Alcohol Fuels: Policies, Production and Potential, West view Press (Boulder), Colorado, 1-19, pp. 37-80.

Kosaric, N., Duvnja, Z., and Stewart, G.G., (1981), Fuel Ethanol from Biomass: Production, Economics and Energy, Biotech. Bioeng., Vol 20, pp. 119-151.

Mochida, I., Yoon, S.H., and Qiao, W., (2006), Catalysts in Syntheses and Carbon Precusors, J. Braz. Chem. Soc., 17(6), pp. 1059-1073.

Koyotaka, N. and Michikazu, H., (2007), Environmentally Benign Production of Chemicals and Energy Using a Carbon-Based Strong Solid Acid, Journal of American Ceramic Society, 90(12), pp. 3725-3734.

Onda, A., Ochi, T., and Yanagisawa, K., (2008), Selective hydrolysis of cellulose over solid acid catalysts, Green Chemistry, 10, pp. 1033-1037.

Onda, A., Ochi, T., and Yanagisawa, K., (2009), Hydrolysis of Cellulose Selectively into Glucose Over Sulfonated Activated-Carbon Catalyst Under Hydrothermal Conditions, Topics in Catalysis, 52, pp. 801-807.

Taherzadeh, M.J. and Karimi, K., (2007a), Acid-based hydrolysis processes for ethanol from lignocellulosic materials, a review, Bioresources, 2(3), pp. 472-499.

Taherzadeh, M.J. and Karimi, K., (2007b), Enzymebased hydrolysis processes for ethanol from lignocellulosic materials, a review, Bioresources, 2(4), pp.707-738.

Xiang. Q., Lee. Y.Y., Petterson. P.O., and Torget. R.W., (2003), Heterogeneous Aspects of Acid Hydrolysisi of $\alpha$-Cellulose, Applied Biochemistry and Biotechnology, 103, pp. 505-514. 